\title{
Assessing the Transition from Survival to Sustainability: Case of Wechiau Community Hippo Sanctuary in Upper West Region of Ghana, West Africa
}

\author{
Olawale E. Olayide ${ }^{1}$, Labode Popoola ${ }^{1}$, Olanrewaju Olaniyan ${ }^{1}$, Frederick Dapilah ${ }^{2} \&$ R.Y. Abudulai Issahaku ${ }^{3}$ \\ ${ }^{1}$ Centre for Sustainable Development, University of Ibadan, Nigeria \\ ${ }^{2}$ University for Development Studies, Wa, Upper West region, Ghana \\ ${ }^{3}$ Wechiau Hippo Sanctuary, Wa, Upper West Region, Ghana \\ Correspondence: Olawale E. Olayide, Centre for Sustainable Development, University of Ibadan, Nigeria. \\ E-mail: oe.olayide@ui.edu.ng,waleolayide@yahoo.com,waleolayide@gmail.com
}

Received: March 28, 2013 Accepted: August 21, 2013 Online Published: September 17, 2013

doi:10.5539/jsd.v6n10p47 URL: http://dx.doi.org/10.5539/jsd.v6n10p47

\begin{abstract}
In the past 50 years, humans have changed ecosystems more rapidly to meet growing demands for food, fresh water, timber, fibre and fuel. This has resulted in substantial decrease in biodiversity, including the hippopotamus (hippo) population. There are currently about 150,000 hippos left in the world. Their status will change from vulnerable to endangered if threats are not controlled. The threats include destructive exploration and exploitation for human survival through hunting for ivory and meat, habitat loss due to flooding and destruction of hippo lawns along river banks. Sustainable exploration of biodiversity on the other hand ensures a balance in nature through synergistic cooperation in ecosystem services, human well-being as well as the direct and indirect drivers of change. This study assessed the emerging transition from survival to sustainability in the management of community-based biodiversity management in Ghana.

Ghana has two hippo populations; one at Bui National Park and the other at the Wechiau Community Hippo Sanctuary (WCHS). The WCHS was established in 1998. It was chosen for in-depth analysis and assessment. The ecosystem assessment framework of interaction between ecosystems and drivers of global change was adopted for the study. The assessment was based on "before" and "now" scenarios to draw inferences for impact of community-based biodiversity management and sustainability.

The WCHS provides economic alternatives to converting community-based ecosystems into sustainable economic ventures, including eco-tourism. The number of tourists to WCHS that stood at less than 500 persons in 2002 increased to 2,390 persons in 2011. The test of correlation between the number of local and foreign tourists revealed significant $(\mathrm{p}<0.001 ; \rho=0.926)$ relationships in the influx of tourists to WCHS. This is evident by the increase in revenue that accrued to the WCHS. It also generated peaceful cohesion and aesthetics of the environment and development of property rights. The WCHS has led to the reduction in poverty and hunger through the generation of incomes, improvement in health through infrastructural provision, and biodiversity sustainability of local species.

The case of WCHS demonstrates that biodiversity management founded on good communal relationships cannot only improve the livelihoods of the rural poor but also increase their resilience to face challenges as the people become more economically and socially resilient, and empowered to handle future threats to ecological imbalances.
\end{abstract}

Keywords: ecosystem management, eco-tourism, human welfare, sustainable development

\section{Introduction}

There has been growing concern on the alarming rate of biodiversity degradation and reduction in the global coverage of protected areas (Rodrigues et al., 2004; Carwardine et al., 2008). The socio-economic and environmental impacts species extinction and resultant ecological imbalance far outweighs the short-term economic gains of unsustainable exploitation of natural resources (including, flora and fauna) by humans, (Balmford et al., 2001; Sachs et al., 2009). Hence, the need to devise better strategies for managing ecological 
resources. Adaptive management strategy has been proposed to aid the management of community-based natural resources. Such an intervention takes into cognisance the ethical and pragmatic grounds of the dominant natural resource (Rodrigues et al., 2004; Walpole \& Wilder, 2008), as against outright conservation strategy (Asase et al., 2006; Roe, 2008; Sheppard et al., 2010).

According to the Millennium Ecosystem Assessment (2005), 60 percent (that is, 15 out of 24) of the ecosystem services examined during the Millennium Assessment are being degraded or used unsustainably, including fish water, capture fishes, air and water purification, and the regulation of regional and local climate, natural hazards, and pests. They reported further that many ecosystem services have been degraded as a consequence of actions taken to increase the supply of other services, such as food for survival. These trade-offs often shift the costs of degradation or biodiversity loss from one group of people to another or defer costs to future generations. However, many possible options exist to conserve or enhance specific ecosystem services in ways that reduce negative trade-offs or that provide positive synergies with other ecosystem services. Further, poverty in African rural communities renders the effects of degradation harmful and deleterious. The harmful effects of the degradation of ecosystem services (the persistent decrease in the capacity of an ecosystem to deliver services) are being borne disproportionately by the poor, are contributing to growing inequalities and disparities across groups of people, and are sometimes the principal factor causing poverty and social conflicts. The condition and management of ecosystem services is a dominant factor influencing prospects for reducing poverty (Sachs et al., 2009; Millennium Ecosystem Assessment, 2005).

More generally, any progress achieved in addressing the Millennium Development Goals (MDGs) on eradication of poverty and hunger, improvement in health, and environmental sustainability is unlikely to be sustained if most of the ecosystem services on which humanity relies continue to be degraded. In contrast, the sound management of ecosystem services provides cost-effective opportunities for addressing sustainable development goals in a synergistic manner. Degradation of ecosystem services exacerbates poverty in developing countries, which can affect neighbouring industrial countries by slowing regional economic growth and contributing to the outbreak of conflicts or the migration of refugees (Millennium Ecosystem Assessment, 2005).

The present study established the basis for conservation and sustainable use of ecosystems and their contributions to survival and human well-being, using the case of WCHS. According to the Millennium Ecosystem Assessment (2005), an ecosystem is a dynamic complex mixture of plants, animals, and microorganisms in communities and the non-living environment interacting as a functional unit. Ecosystem services are on the other hand the benefits people obtain from ecosystems. They include provisioning services such as food, water timber, and fibre; regulating services that affect climate, floods, disease, wastes, and water quality, cultural services that provide recreational, aesthetic, and spiritual benefits; and supporting services such as soil formation, photosynthesis, and nutrient cycling. Changes in ecosystem services influence human well-being, survival, and sustainability of the ecosystem (Millennium Ecosystem Assessment, 2005).

Human survival is driven by a craving for basic materials for a good life, such as secure and adequate livelihoods, enough food at all times, clothing and access to goods; health, including feeding well and having a healthy physical environment, such as clean air and access to clean water; good social relation, including social cohesion, mutual respect, and the ability to help others and provide for children; security, including secure access to natural and other resources, personal safety, and security from natural and human-made disasters; and from freedom of choice and action, including the opportunity to achieve what an individual values doing and being (Millennium Ecosystem Assessment, 2005; World Resources, 2005).

Social, economic and cultural factors influence sustainable development of biodiversity. Besides, the survival instinct and destructive exploitation of natural resources (fauna and flora) suggests that the actions people take that influence ecosystems result not just from concern about human well-being but also from considerations of the intrinsic value of species and ecosystems (Millennium Ecosystem Assessment, 2005).

The total economic value associated with managing ecosystems more sustainably is often higher than the value associated with the conversion of the ecosystem through farming, clear-cut logging, or other intensive uses. Besides, it has been established by some studies that the benefit of managing ecosystems more sustainably exceeded that of converting the ecosystem (Millennium Ecosystem Assessment, 2005; World Resources, 2005).

Further, it has been noted that sustainable use of ecosystem services promotes enhancement of its regulating, supporting and cultural potentials, which means increased production (per unit area) of the services, including recreational and aesthetic benefits of natural resources. Olayide et al. (2011), Kinzig et al. (2006), Wesley et al. (2002), and Kinzig (2001) have demonstrated the need to couple ecological and socioeconomic domains when examining dynamics of systems of natural resource management. 
Humanity is a major force in global change and shapes ecosystem dynamics from local environments to the biosphere as a whole (Redman, 1999; Steffen et al., 2004; Kirch, 2005; Folke, 2006). At the same time, human societies and globally interconnected economies rely on ecosystems services and support (Millennium Ecosystem Assessment, 2005). It is now clear that patterns of production, consumption and wellbeing develop not only from economic and social relations within and between regions but also depend on the capacity of other regions' ecosystems to sustain them (Arrow et al., 1995; Folke et al., 1998, 2006). Costanza et al. (2000) and Lambin (2005) submitted that a major challenge of natural resource management is developing governance systems that make it possible to relate to environmental assets in a fashion that secures their capacity to support societal development for a long time into the future - sustainability. Hence, resilience and transformability (or change) in ecological, economic, or social structures create new ways of living (Walker et al., 2004; Folke, 2006). The resilience perspective is increasingly used as an approach for understanding the dynamics of social-ecological systems (Folke, 2006). Walker et al. (2004) submitted that knowing if, when, and how to initiate transformative change, before it is too late to escape a seriously undesirable and deepening circumstances, is at the heart of social, ecological systems transformability.

We therefore, provide insights into overarching questions on natural resource management, through discussion with stakeholders and elicited responses in the framework of ecosystem services for sustainable development. It set out to underscore the importance of resilience and transformability in economic viability, socio-cultural acceptance, and environmental impact as they relate to natural resource management of the Hippopotami in WCHS.

\section{Conceptual Framework}

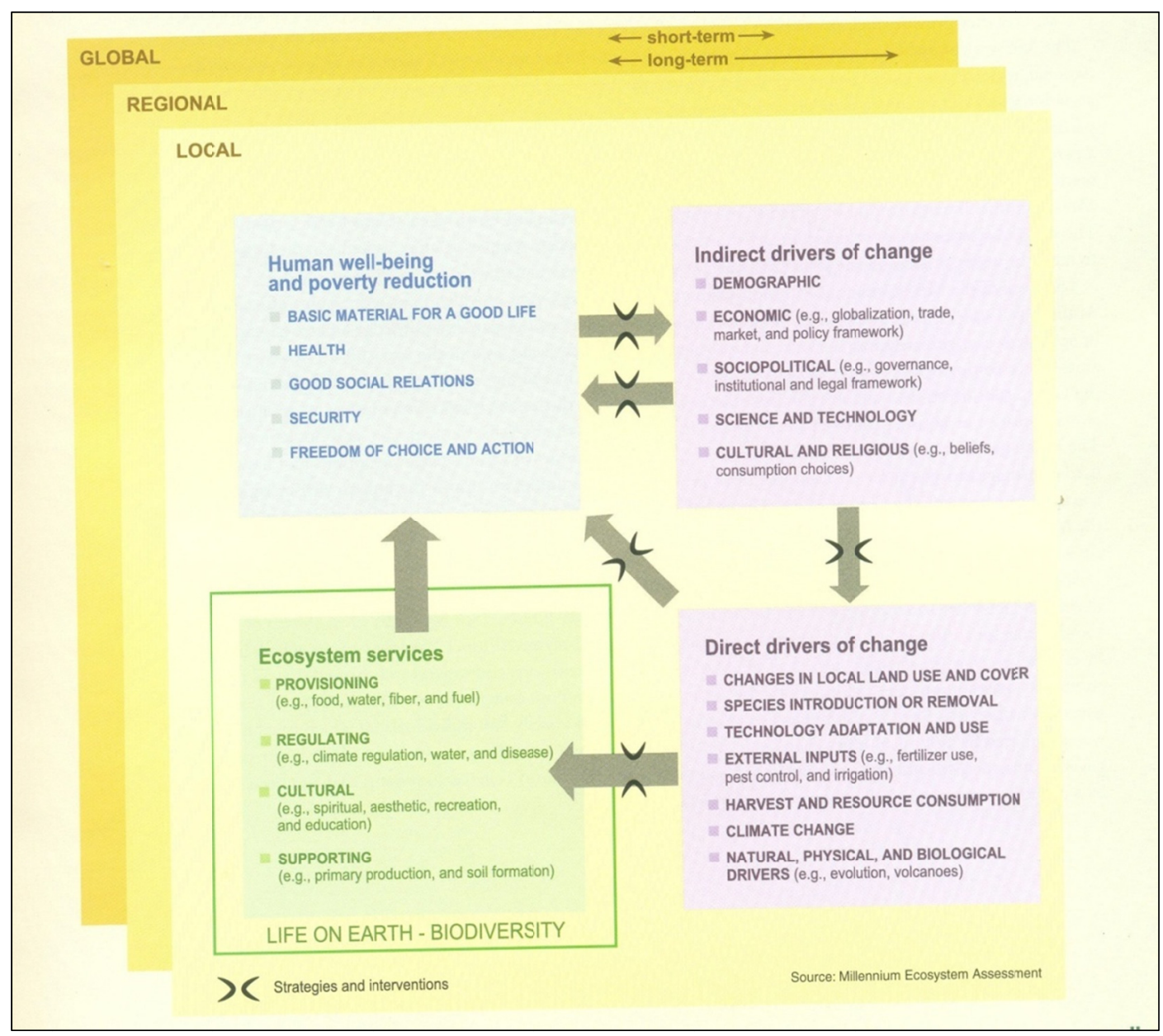

Figure 1. Adapted conceptual framework for the study

Source: Millenniun Ecosystem Asssessment, 2005. 
The conceptual framework used for the study (Figure 1) follows that of the Millennium Ecosystem Assessment (2005) that suggests that changes in drivers that indirectly affect biodiversity, such as population, technology, and lifestyle, can lead to changes in drivers directly affecting biodiversity, such as the catch of fish (or hippos). The results in changes to ecosystems and the services they provide, thereby affecting human survival, hence sustainability. These interactions can take place at more than one scale and can cross scales in time and space. Different strategies and interventions can be applied at any in this framework and conserve ecosystems (Millennium Ecosystem Assessment, 2005; World Resources, 2005). This study presents a scenario in which global discussions around issues of sustainability and development are brought to the local ground-level and interpreted through the case study of the WCHS.

The case of WCHS fits into the context of community-based management of biodiversity of endangered species of the hippo population to the extent of deriving optimum ecosystem services for sustainable development through economic (improved livelihoods and poverty reduction), socio-cultural (infrastructural development, security and communal work), environmental (increase in hippo population and reduced environmental degradation) benefits (World Resources, 2005).

\section{Methodology}

The case study is Wechiau Community Hippo Sanctuary in the Upper West Region of Ghana. The study location has tropical climatic characteristics that favour the population of common hippopotamus (Hippopotamus amphibius). However, the area is dominated by poverty which often led to heavy predation on the hippopotami for human survival (Brashares et al., 2004; CPRC [Chronic Poverty Research Centre], 2009), Sheppard et al., 2010).

Primary data were gathered through key informant interviews and focus group discussions organized in the community, including youth, men, women and WCHS Management Team. Responses were then categorized to extract summary statistics. Qualitative and quantitative data were analyzed to underscore the importance of the transition from imminent degradation to sustainability of the focal species of Hippopotami.

We investigated the factors (changes) influencing the transition from survival to sustainability of the WCHS. Olawoye (2012) highlighted the factors that affect sustainability as including, economic viability, social acceptability and level of local participation as well as environmental impact. Dyllick and Hockerts (2002) state that the sustainable development debate is based on the assumption that societies need to manage three types of capital (economic, social and natural), which may be non-substitutable and whose consumption might be irreversible. It has been suggested that the outcomes of the sustainability of community-based natural resource management should include, social, economic and environmental benefits (Kellert et al., 2000; Weber et al., 2005; Plummer \& Armitage, 2007; Sheppard et al., 2010).

We therefore, considered the three broad aspects of sustainable development. The aspects are economic, socio-cultural and infrastructural, and environmental and biodiversity outcomes. The economic aspect comprises such indices as number of visitors (tourists) per month, revenue per month (from eco-tourism), level of poverty and inequality, and number of people in the community (population density). The socio-cultural aspect covers support from government, relationships between communities, relationship between Ghana and Burkina Faso, relationship between management team, political participation, number of NGOs and CBOs, level of communal conflicts while the infrastructural change includes the number of primary schools, number of health facilities (clinics and hospitals), access to credit, road infrastructure, access to production inputs, housing units, sanitation facilities. The environmental and biodiversity aspect encompasses the involvement community members in extractive business as main occupation, and trends in the number of hippos in the Volta River.

\section{Results and Discussion}

The discussion of the results was based on the three identified aspects of sustainability (transformability) economic, socio-cultural, and environmental outcomes. The data gathered through key informant interviews and focus group discussions demonstrate multi-scalar experiences of sustainability and development. The qualitative (and quantitative) data presented represent the consensus of the key informants that were interviewed and of the participants of focus groups (men, women, youth and WCHS management team). Activities of the WCHS were shaped by local, regional, and global forces - governance and eco-tourism. Eco-tourism is a local, regional, and global social practice. The multi-scalar dimensions of eco-tourism support ecosystem management, human welfare and sustainable development. 


\subsection{Economic and Livelihoods Aspect}

The economic activities of the community have witnessed some improvements as a result of the establishment of the Hippo Sanctuary (Table 1). The economic prospects of the community have changed significantly. The community that was predominantly agrarian has witnessed expansion and diversification of livelihoods from such enterprises as farming, trading and catering services (particularly food vending and petty outfits), metal works, auto mechanics, agro-processing (oil extraction), hospitality industry, water distilling, tourism/conservation, arts and craft, masonry, fashion design, textiles (cloth/smock weaving, batik), electronic (repair works), pottery, wood work (carpentry), fishing, to tourists gardens through river safari to see Hippos, bird watching with about 250 species within the area, and patronage of culture of the indigenous people that make up the sanctuary.

The economic fortune of the community has been transformed from reduction in poverty and inequality. The qualitative data gathered suggest that the level of poverty and inequality has reduced. There is also increase in the population density in the community. The community through the WCHS management committee now earns an average of Gh $\phi 2,800$ (USD 1,474) per month from tourism activities. The revenue that is generated is ploughed to the development of basic social infrastructures like schools, water and sanitation facilities and local resort for visitors.

Table 1. Economic changes

\begin{tabular}{lll}
\hline Indicators & Before 1998 & Now (2012) \\
\hline Revenue per month (from tourism) & None & Ghф 2,800 (USD 1,474) \\
Level of poverty and inequality & High & Reduced \\
Number of people in the community (population)* & Low density & Increased (moderate density) \\
Number of visitors (tourists) per month & 15 & $200-300$ \\
\hline
\end{tabular}

*Indicator for market potentials (access) and commercialization (Olayide et al., 2011).

Consequently, the number of local and international tourists to WCHS has increased phenomenally (Figure 2). The number of tourists to WCHS that stood at less than 500 persons in 2002 increased to 2,390 persons in 2011. Visitors are increasingly making the WCHS a beehive of activity. The number of foreign tourists surpassed local tourists in 2002, 2003, and 2005, respectively. The implication of the influx of tourists to WCHS is evident by increased revenue generated and patronage of local enterprises. The correlation test statistic revealed a significant and a high level of correlation $(\mathrm{p}<0.001 ; \rho=0.926)$ between foreign and local tourists; implying that both local and foreign tourists appreciate the hippo sanctuary as a tourist destination. 


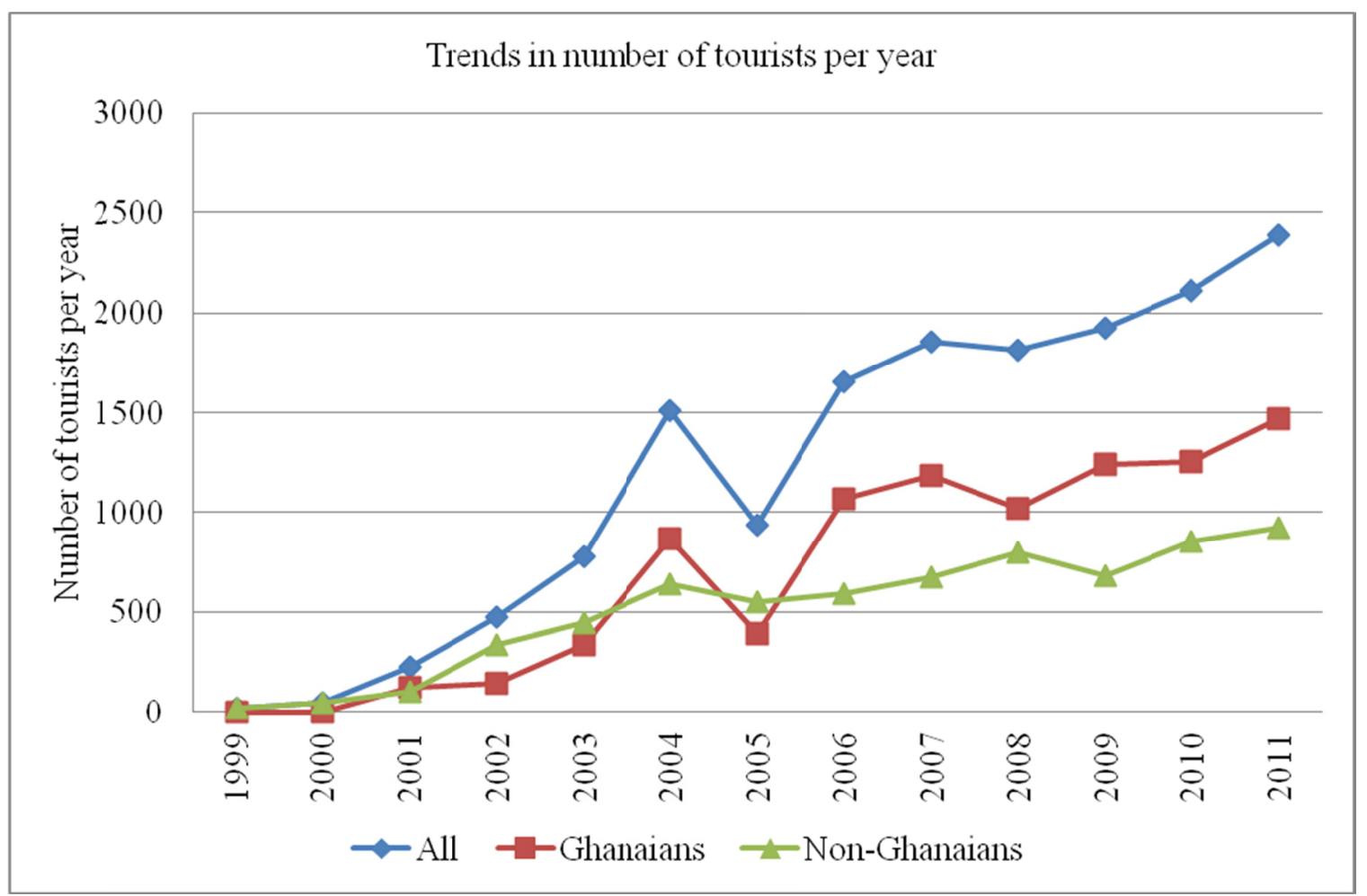

Figure 2. Trends in number of tourists to WCHS per year $(1999-2011)$

\subsection{Socio-Cultural and Infrastructural Aspect}

Socio-cultural and infrastructural changes occurred in the following areas: support from government which was low before the advent of WCHS has now improved including, government intervention projects like paving of roads (Table 2). The relationship among the 17 communities in the area is now cordial. The system of local governance and selection process into the Management Board of the Sanctuary is viewed as transparent and acceptable to all stakeholders, including some Non-Governmental organizations. There is also a long-standing relationship between Ghana and Burkina Faso that helped to reduce communal conflicts in the area. Infrastructural transformation of the communities is also obvious. For instance, the number of primary schools increased from three in 1998 to ten in 2012; though there is still no secondary school to service the 17 communities in the area. The number of health facilities (clinics and hospitals) has improved considerably, with the number of facilities increasing from one in 1998 to three in 2012. Similarly, access to credit and personal cash increased with more income from diversification in own enterprises and loans from local lenders. Access to production inputs (e.g., farm inputs) also boosted production base and commercialization of agricultural production in the communities. This has led to upstream and downstream processes especially in the agricultural sector. There was also improvement and diversification in the skill sets of employees in the communities. Another evidence of development in the area was the increase in housing units and type. Due to the availability of more disposable income, people now invest in the development of more housing units including concrete (rather than mud) houses. This has implications for the welfare of the people in the communities. 
Table 2. Socio-cultural and infrastructural changes

\begin{tabular}{lll}
\hline Indicators & Before 1998 & Now (2012) \\
\hline Support from government & low & Improved (road networks) \\
Relationship among communities & strained & cordial \\
Relationship Between Ghana and Burkina Faso & cordial & cordial \\
Relationship between Management team & none & cordial \\
Political Participation & low & high \\
Number of NGOs and CBOs & none & five (5) \\
Level of communal conflicts & high & reduced \\
Number of Primary Schools & three & ten \\
Number of Secondary schools & none & none \\
Number of health facilities (clinics and hospitals) & one & three \\
Sanitation facilities & poor & improved \\
Road infrastructure & worse & improved \\
Access to cash and credit & low & improved \\
Access to production inputs & low & improved \\
Housing units & low & increased \\
\hline
\end{tabular}

\subsection{Environmental and Biodiversity Aspect}

The main occupation of the people remains farming (Table 3). This primary extractive business impacts on the environment. It was gathered that despite the sprawling business of eco-tourism offered by the Sanctuary, more than $70 \%$ of the people are still involved in agricultural production. However, the Sanctuary area is protected. The population of hippos, which was near extinction in 1998 due to heavy human predation, and encroachment as means of survival through hunting, has now increased to 27 hippos.

The cultural norms and taboos of the dominant tribes (Wala and Birifor) in the community contributed significantly to the protection of the hippos and the Sanctuary. The socio-cultural beliefs of the community reinforce the success in the conservation of the biodiversity of the Sanctuary. Hence, this result underscores the importance of socio-cultural beliefs in the management of community-based natural resources, especially in West African communities (Assenheim, 2000; Sheppard et al., 2010).

Table 3. Environmental and biodiversity changes

\begin{tabular}{lll}
\hline Environmental and resource change & Before 1998 & Now (2012) \\
\hline Main occupation of the people & Farming & Farming \\
Number of Hippos & 14 & 27 \\
\hline
\end{tabular}

\section{Conclusion: From Survival to Sustainability?}

The establishment through compromise for a sanctuary rather than exclusive protected area has reinforced the effectiveness of community-based approach to natural resource management of focal species in WCHS. It is a testimonial of the sustainability of natural resource management of biodiversity and ecosystems. It is a case that informs a wider audience about using economic instruments for bio-diversity conservation, and promoting sustainable development.

The converse of business as usual or no conservation scenario would have reduced the population of hippos further or to outright extinction. The counterfactual of the benefits of economic, social, and biodiversity and eco-tourism are rather grave. However, the community needs to put in place effective control of the hippos 
population to determine appropriate threshold to enhance ecological balance and forestall threats to humans and the environment.

Consensus from the groups interviewed (men, women, youth and WCHS management team), and subsequent analyses bear testimonies of the positive impacts of WCHS. Socio-cultural, economic and ecological transformations are taking place as a result of the WCHS. Proceeds from eco-tourism are ploughed back into developmental projects such as construction of schools, boreholes and small-scale businesses in the communities. Such developmental projects are promoting equitable distribution of benefits and improved trust networks. Additionally, WCHS provides economic opportunities for converting community-based ecosystems into sustainable economic ventures for the people. It has also promoted peaceful cohesion between Burkina Faso and Ghana, and surrounding communities to the Hippo Sanctuary.

Overall, the WCHS is a success story in the management of ecosystem biodiversity, and promotion of eco-tourism as an avenue for achieving wildlife conservation and transition to sustainable development. It reveals a win-win situation of the dilemma often encountered in ecosystem management. However, for long-term sustainability, the stakeholders (government and the community) should continue to work together to sustain the transition to sustainable development with a view to mitigating social, economic and ecological threats to the sanctuary.

\section{Acknowledgements}

The authors would like to thank the graduate students of the Master's in Development Practice (MDP) Programme at the Centre for Sustainable Development, University of Ibadan, Nigeria, for their support during our field trips. The authors also thank anonymous reviewers for their constructive comments.

\section{References}

Arrow, K., Bolin, B., Costanza, R., Dasgupta, P., Folke, C., Holling, C. S., ... Pimentel, D. (1995). Economic growth, carrying capacity and the environment. Science, 268, 520-521. http://dx.doi.org/10.1126/science.268.5210.520

Asase, A., Oteng-Yeboah, A. A., \& Mason, J. (2006). Engaging people in the Wechiau Community Hippopotamus Sanctuary in Ghana. In The Nature of Success: Success for Nature. 6th International Congress on Education in Botanic Gardens, pp. 1-7. Oxford, UK: Botanic Gardens Conservation International.

Assenheim, N. (2000). People of the Wechiau Hippo Sanctuary. Masters thesis, Trent University, Trent, Canada.

Balmford, A., Moore, J. L., Brooks, T., Burgess, N., Hansen, L. A., Williams, P., \& Rahbek, C. (2001). $\begin{array}{lllll}\text { Conservation } & \text { conflicts } & \text { across } & \text { Africa. } & \text { Science, }\end{array}$ http://dx.doi.org/10.1126/science.291.5513.2616

Brashares, J. S., Arcese, P., \& Sam, M. K. (2001). Human demography and reserve size predict wildlife extinction in West Africa. Proceedings of the Royal Society of London Series B. Biological Sciences, 268, 2473-2478. http://dx.doi.org/10.1098/rspb.2001.1815

Brashares, J. S., Arcese, P., Sam, M. K., Coppolillo, P. B., Sinclair, A. R. E., \& Balmford, A. (2004). Bushmeat hunting,wildlife declines, and fish supply in West Africa. Science, 306, 1180-1183. http://dx.doi.org/10.1126/science.1102425

Carwardine, J., Wilson, K. A., Ceballos, G., Ehrlich, P. R., Naidoo, R., Iwamura, T., ... Possingham, H. P. (2008). Cost-effective priorities for global mammal conservation. Proceedings of the National Academy of Sciences of the United States of America, 105, 11446-11450. http://dx.doi.org/10.1073/pnas.0707157105

Costanza, R., Daly, H. E., Folke, C., Hawken, P., Holling, C. S., McMichael, T., ... Rapport, D. J. (2000). $\begin{array}{llll}\text { Managing our environmental portfolio. BioScience, 50, 149-155. } & \text {. }\end{array}$ $\mathrm{http}: / / \mathrm{dx}$. doi.org/10.1641/0006-3568(2000)050[0149:MOEP]2.3.CO;2

CPRC. (2009). The chronic poverty report 2008-2009: escaping poverty traps. Retrieved from http://www.chronicpoverty.org/uploads/publicationfiles/CPR2_ReportFull

Dyllick, T., \& Hockerts, K. (2002). Beyond the business case for corporate sustainability. Business Strategy and the Environment, 11(2), 130-141. http://dx.doi.org/10.1002/bse.323

Folke, C. (2006). Resilience: The emergence of a perspective for social-ecological systems analyses. Global Environmental Change, 16, 253-267. http://dx.doi.org/10.1016/j.gloenvcha.2006.04.002 
Folke, C., Pritchard, L., Berkes, F., Colding, J., \& Svedin, U. (1998). The Problem of Fit between Ecosystems and Institutions. International Human Dimensions Programme (IHDP). IHDP Working Paper No 2. Retrieved from www.uni-bonn.de/IHDP/public.htm

Kellert, S. R., Mehta, J. N., Ebbin, S. A., \& Lichtenfeld, L. L. (2000). Community natural resource management: promise, rhetoric and reality. Society and Natural Resources, 13, 705-715. http://dx.doi.org/10.1080/089419200750035575

Kinzig, A. P. (2001). Bridging disciplinary divides to address environmental challenges. Ecosystems, 4(8), 709-715. http://dx.doi.org/10.1007/s10021-001-0039-7

Kinzig, A. P., Ryan, P., Etienne, M. H., Allison, T., Elmqvist, \& Walker, B. H. (2006). Resilience and regime shifts: assessing cascading effects. Ecology and Society, 11(1), 20. Retrieved from http://www.ecologyandsociety.org/vol11/iss1/art20/

Kirch, P. V. (2005). Archaeology and global change. Annual Review of Environment and Resources, 30, 409-440. http://dx.doi.org/10.1146/annurev.energy.29.102403.140700

Lambin, E. F. (2005). Conditions for sustainability of human-environment systems: information, motivation, and capacity. Global Environmental Change, 15, 177-180. http://dx.doi.org/10.1016/j.gloenvcha.2005.06.002

Lewison, R., \& Oliver, W. (2008). Hippopotamus amphibious. Retrieved from http://www.iucnredlist.org/

Millennium Ecosystem Assessment. (2005). Ecosystems and Human Well-being: Synthesis (p. 137). Island Press, Washington DC. Retrieved from http://www.MAweb.org

Olawoye, J. (2012). Social Context of Sustainability Research and Education in Africa. Presentation at the International Seminar on Sustainability Science Research and Education in Support of Africa's Development held at the University of Tokyo, 1-3 March.

Olayide, E. O., Ikpi, A. E., Alene, A. D., \& Akinyosoye, V. (2011). Assessing Farm-level Limitations and Potentials for Organic Agriculture by Agro-ecological Zones and Development Domains in Northern Nigeria of West Africa. J Hum Ecol, 34(2), 75-85.

Plummer, R., \& Armitage, D. (2007). A resilience-based framework for evaluating adaptive co-management: linking ecology, economics and society in a complex world. Ecological Economics, 61, 62-74. http://dx.doi.org/10.1016/j.ecolecon.2006.09.025

Redman, C. L. (1999). Human Impact on Ancient Environments. Tucson AZ: The University of Arizona Press.

Rodrigues, A. S. L., Andelman, S. J., Bakarr, M. I., Boitani, L., Brooks, T. M., Cowling, R. M., ... Yan, X. (2004). Effectiveness of the global protected area network in representing species diversity. Nature, 428, 640-643. http://dx.doi.org/10.1038/nature02422

Roe, D. (2008). The origins and evolution of the conservation-poverty debate: a review of key literature, events and policy processes. Oryx, 42, 491-503. http://dx.doi.org/10.1017/S0030605308002032

Sachs, J. D., Baillie, J. E. M., Sutherland, W. J., Armsworth, P. R., Ash, N., Beddington, J., ... Jones, K. E. (2009). Biodiversity conservation and the Millennium Development Goals. Science, 325, 1502-1503. http://dx.doi.org/10.1126/science.1175035

Sheppard, D. J., Moehrenschlager, A., Mcpherson, J. M., \& Mason, J. J. (2010). Ten years of adaptive community-governed conservation: evaluating biodiversity protection and poverty alleviation in a West African hippopotamus reserve. Environmental Conservation, 37(3), 270-282. http://dx.doi.org/10.1017/S037689291000041X

Steffen, W., Sanderson, A., Jager, J., Tyson, P. D., Moore, B., Matson, P. A., ... Wasson, R. J. (2004). Global Change and the Earth System: A Planet under Pressure. Germany: Springer, Heidelberg.

UNEP-WCMC. (2008). State of the world's protected areas: an annual review of global conservation progress. Retrieved from http://www.unep-wcmc.org/protected_areas/pdf/stateOfTheWorld'sProtectedAreasLow.pdf

Walker, B., Holling, C. S., Carpenter, S. R., \& Kinzig, A. (2004). Resilience, adaptability and transformability in social-ecological systems. Ecology and Society, 9(2), 5. Retrieved from http://www.ecologyandsociety.org/vol9/iss2/art5

Walpole, M., \& Wilder, L. (2008). Disentangling the links between conservation and poverty reduction in practice. Oryx, 42, 539-547. http://dx.doi.org/10.1017/S0030605308000744 
Weber, E. P., Lovrich, N. P., \& Gaffney, M. (2005). Collaboration, enforcement, and endangered species: a framework for assessing collaborative problem-solving capacity. Society and Natural Resources, 18, 677-698. http://dx.doi.org/10.1080/08941920591005034

Wells, M., \& McShane, T. O. (2004). Integrating protected area management with local needs and aspirations. Ambio, 33, 513-519.

Westley, F., Carpenter, S. R., Brock, W. A., Holling, C. S., \& Gunderson, L. H. (2002). Why systems of people and nature are not just social and ecological systems. In L. H. Gunderson, \& C. S. Holling (Eds.), Panarchy: understanding transformations in human and natural systems (pp. 103-120). Washington, D.C., USA: Island Press.

World Resources. (2005). The Wealth of the Poor: Managing Ecosystems to Fight Poverty (pp. 254). Washington DC: World Resources Institute.

\section{Copyrights}

Copyright for this article is retained by the author(s), with first publication rights granted to the journal.

This is an open-access article distributed under the terms and conditions of the Creative Commons Attribution license (http://creativecommons.org/licenses/by/3.0/). 